\title{
55. PETROLOGY OF BASALTS, GABBROS, AND PERIDOTITES FROM DSDP LEG 37
}

\author{
F.N. Hodges and J.J. Papike, Department of Earth and Space Sciences, \\ State University of New York, Stony Brook, New York
}

\begin{abstract}
Drilling at Site 332 recovered a wide variety of relatively fresh, chemically primitive, low-titanium, olivine or olivine-plagioclase phyric tholeiitic basalts. Apparent crystallization sequences are either olivine + chromite, plagioclase, clinopyroxene, titanomagnetite or olivine + plagioclase ( \pm chromite), clinopyroxene, titanomagnetite. $\mathrm{Cr}$ in pyroxenes falls off rapidly with crystallization, followed by a decrease in $\mathrm{Al}$ and an increase in $\mathrm{Ti}$, reflecting chemical changes in the host melts with advancing crystallization,

Coarse-grained rocks recovered at Site 334 are serpentinized Iherzolitic peridotites and two pyroxene gabbros \pm olivine. Textures and primary pyroxene compositions indicate crystallization from a low-alkali, olivine tholeiite magma. Complex exsolution features and a high degree of equilibration within pyroxenes indicates a long cooling and annealing time within the oceanic crust, probably within layer 3 .
\end{abstract}

\section{SITE 332}

Drilling at Holes $332 \mathrm{~A}$ and $332 \mathrm{~B}$ penetrated a total of 915.5 meters of igneous basement. This report includes brief descriptions and mineral chemical data for eight samples, three from $332 \mathrm{~A}$ and five from 332B, representing 7 of 18 lithologic units recognized by shipboard scientists. Major and trace element data for five of these samples (332A-34-2, 6-9 cm; 332B-2-5, 109-111 $\mathrm{cm} ; 332 \mathrm{~B}-19-1,107-110 \mathrm{~cm}$; 332B-21-1, 27-30 cm; 332B$22-4,18-20 \mathrm{~cm}$ ) are presented by Bence and Taylor (this volume).

Three of the samples (332A-7-1, 37-39 cm; 332A-342 , 6-9 $\mathrm{cm}$; and $332 \mathrm{~B}-2-5,109-111 \mathrm{~cm}$ ) are vesicular plagioclase-olivine phyric basalts (plag. $>>$ ol). Plagioclase phenocrysts occur principally as complex, multiple grains with numerous melt inclusions. Poorly developed oscillatory zoning is present within some grains, and strong normal zoning is present in narrow rims adjacent to the groundmass. Plagioclase phenocryst contents range from approximately 30 volume \% in 332B-2-5, $109-111 \mathrm{~cm}$ to approximately 10 volume \% in $332 \mathrm{~A}-34-2,6-9 \mathrm{~cm}$. Olivine occurs as rare phenocrysts in all three samples, in most cases in contact with a plagioclase phenocryst (Plate 1, Figure 1), and in small quantities in the groundmass of Samples $332 \mathrm{~A}-7-1,37-39 \mathrm{~cm}$ and $332 \mathrm{~B}-2-5,109-111 \mathrm{~cm}$. The groundmass in the samples ranges from subvariolitic to subophitic intergrowths of plagioclase and clinopyroxene, with well-developed sector zoning in pyroxene in $332 \mathrm{~A}-34-2,6-9 \mathrm{~cm}$. Anhedral areas of finely crystalline mesostasis, partly replaced by yellow "smectite" are present throughout the sections, and titanomagnetite, occurring principally as skeletal grains, is restricted to this late-stage residuum.
Three of the basalts (332B-19-1, 107-110 cm; 332B$21-1,27-30 \mathrm{~cm}$; and 332B-29-1, 63-66 cm) are vesicular olivine phyric basalts, although one of these (332B-21$1,27-30 \mathrm{~cm})$ contains approximately 15 volume \% olivine "phenocrysts" and might more properly be called picrite. These samples are characterized by abundant fresh olivine and chrome spinel. The latter occurs as inclusions within olivine and as subhedral microphenocrysts. A large part of the olivine in these samples is apparently xenocrystic, with well-developed kink bands, and some multiple grains have $120^{\circ}$ grain intersections (Plate 1, Figure 2), indicating metamorphic recrystallization; however, these samples also contain subhedral olivine with quench overgrowths (Fos8-87) similar in composition to the xenocrystic olivine (Fog $1-87$ ), and Sample 332B-21-1, 27-30 cm contains well-developed skeletal quench olivine within its groundmass (Plate 1, Figure 3). Groundmass textures range from 332B-21-1, $27-30 \mathrm{~cm}$ with well-developed quench forms of plagioclase and olivine set in a very fine grained herringbone intergrowth peppered with iron-titanium oxides, to 332B-19-1, 107-110 cm with subvariolitic to subophitic intergrowths of plagioclase and pyroxene. In addition to the pyroxene quench forms normally found in pillow basalts, Sample 332B-19-1, 107-110 cm contains a form of skeletal clinopyroxene (Plate 1, Figure 4) that is unique in our experience. In coarser grained samples titanomagnetite is restricted to the interstitial residual phase and what may have been residual glass has been replaced by yellow "smectite."

Sample 332B-22-4, $18-20 \mathrm{~cm}$ is a plagioclase-olivine glomeroporphyritic basalt characterized by large (up to $6 \mathrm{~mm}$ ) open intergrowths of plagioclase and olivine (Plate 2, Figure 1). Morphology of the glomerocrysts and zoning trends within the plagioclase indicate that 
the clots grew from the melt and that olivine crystallized slightly before plagioclase. The groundmass is a very fine grained intergrowth similar to that of Sample 332B-21-1, 27-30 cm.

Sample $332 \mathrm{~A}-40-2,57-63 \mathrm{~cm}$ is a highly porphyritic plagioclase-pyroxene-olivine phyric basalt characterized by anhedral olivine phenocrysts (?), subhedral, twinned clinopyroxene phenocrysts, and a variety of plagioclase phenocrysts ranging from large composite grains with numerous melt inclusions, to subhedral grains with reversed zoning. The groundmass consists of a well-developed subophitic intergrowth of plagioclase and clinopyroxene. The relationship of this sample to the others is far from clear, and it may well represent a "hybrid" with a considerable amount of xenocrystic material. In this context it is interesting that the composition of the pyroxene "phenocrysts" is very similar to the bulk composition of augites in olivine gabbro Sample 334-24-3, 55-58 cm.

All of the samples described, with the exception of Sample 332A-40-2, 57-63 cm, are chemically primitive, low-titanium $\left(\mathrm{TiO}_{2}<1\right.$ wt \%) oceanic tholeiites (Bence and Taylor, this volume). The observed crystallization sequences are either olivine + chromite, plagioclase, clinopyroxene, iron-titanium oxides or olivine $( \pm$ chromite) + plagioclase, clinopyroxene, iron-titanium oxides.

Olivine compositions (Table 1) in the samples studied range from 84 to 91 mole \% Fo. The $\mathrm{CaO}$ content of the olivines ranges from 0.27 to 0.49 wt $\%$, and $\mathrm{MnO}$ contents range from 0.10 to $0.25 \mathrm{wt} \%$; however, the narrow compositional range of the olivines, coupled with the variation between samples, makes it extremely difficult to determine whether or not systematic variation is present.

Compositions of chromium-rich spinels (Table 2) are plotted on the faces of the spinel prism (Figure la, b). The analyzed spinels are more primitive (i.e., higher $\mathrm{Cr}_{2} \mathrm{O}_{3}$ and $\mathrm{Mg} / \mathrm{Mg}+\mathrm{Fe}^{2+}$ ) than previously reported analyses of chromium-rich spinels in oceanic tholeiites and are consistent with the major and trace element chemistry of these rocks.

Table 3 and Figures 2, 3, 4, 5, and 6 summarize the principal aspects of the pyroxene mineral chemistry. Data plotted on the pyroxene quadrilateral (Figure 2) show that most are diopsidic augites and that some samples show iron-enrichment trends. The "other" components in the pyroxenes range from $5 \%$ to $15 \%$ (Table 3) and can be characterized by reference to the following charge balance equation (Papike et al., 1974):

$$
\begin{aligned}
& \text { Charge Excess Charge Deficiencies } \\
& \text { Relative to Quad Relative to Quad } \\
& \mathrm{VI}_{\mathrm{Al}}+\mathrm{VI}_{\mathrm{Fe}^{3+}}{ }^{3+} \mathrm{VI}_{\mathrm{Cr}^{3++}}{ }_{2} \mathrm{VI}_{\mathrm{Ti}^{4+}}=\mathrm{IV}_{\mathrm{Al}} \text {. }
\end{aligned}
$$

This simply states that the pyroxene "other" components have the following types of coupled substitutions:

$$
\begin{gathered}
\mathrm{VI}_{\mathrm{Al}}-\mathrm{IV}_{\mathrm{Al}}, \mathrm{VI}_{\mathrm{Fe}^{3+}-\mathrm{IV}_{\mathrm{Al}},} \\
\mathrm{VI}_{\mathrm{Cr}}{ }^{3+-\mathrm{IV}_{\mathrm{Al}}}, \mathrm{VI}_{\mathrm{Ti}^{4+}-}{ }^{4+} \mathrm{IV}_{\mathrm{Al}}
\end{gathered}
$$

\begin{tabular}{|c|c|c|c|c|c|c|c|}
\hline $\begin{array}{c}\text { Sample } \\
\text { (Interval in } \mathrm{cm} \text { ) }\end{array}$ & 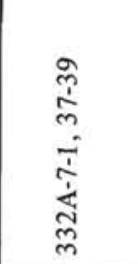 & 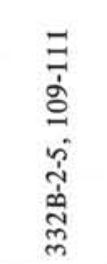 & 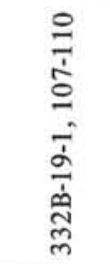 & 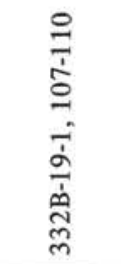 & 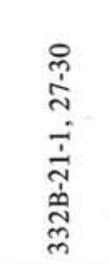 & 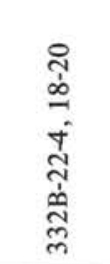 & 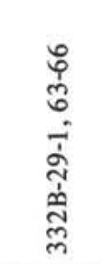 \\
\hline $\mathrm{SiO}_{2}$ & 40.11 & 40.04 & 39.72 & 40.25 & 39.82 & 39.30 & 39.82 \\
\hline $\mathrm{Al}_{2} \mathrm{O}_{3}$ & 0.05 & 0.00 & 0.00 & 0.00 & 0.05 & 0.00 & 0.00 \\
\hline "FeO" & 10.72 & 10.88 & 12.44 & 12.17 & 11.84 & 13.99 & 10.54 \\
\hline $\mathrm{MnO}$ & 0.22 & 0.20 & 0.20 & 0.16 & 0.21 & 0.21 & 0.20 \\
\hline $\mathrm{MgO}$ & 48.61 & 48.01 & 47.02 & 47.70 & 46.77 & 45.59 & 48.03 \\
\hline $\mathrm{CaO}$ & 0.47 & 0.37 & 0.37 & 0.36 & 0.42 & 0.32 & 0.34 \\
\hline $\mathrm{Cr}_{2} \mathrm{O}_{3}$ & 0.05 & 0.03 & 0.05 & 0.06 & 0.07 & 0.05 & 0.08 \\
\hline$\Sigma$ & 100.23 & 99.55 & 99.80 & 100.70 & 99.19 & 99.46 & 99.01 \\
\hline $\mathrm{Si}$ & 0.987 & 0.992 & 0.990 & 0.992 & 0.995 & 0.990 & 0.991 \\
\hline $\mathrm{Al}$ & 0.002 & 0.000 & 0.000 & 0.000 & 0.002 & 0.000 & 0.000 \\
\hline $\mathrm{Fe}$ & 0.221 & 0.226 & 0.259 & 0.251 & 0.248 & 0.295 & 0.220 \\
\hline $\mathrm{Mn}$ & 0.005 & 0.004 & 0.004 & 0.003 & 0.005 & 0.004 & 0.004 \\
\hline $\mathrm{Mg}$ & 1.784 & 1.774 & 1.746 & 1.751 & 1.742 & 1.711 & 1.782 \\
\hline $\mathrm{Ca}$ & 0.0123 & 0.010 & 0.010 & 0.010 & 0.011 & 0.008 & 0.009 \\
\hline $\mathrm{Cr}$ & 0.001 & 0.001 & 0.001 & 0.001 & 0.001 & 0.001 & 0.002 \\
\hline $\mathrm{Fe}^{2+} / \mathrm{Fe}^{2+}+\mathrm{Mg}$ & 0.11 & 0.11 & 0.13 & 0.13 & 0.12 & 0.15 & 0.11 \\
\hline$\% \mathrm{Fo}$ & 88.8 & 88.5 & 86.9 & 87.3 & 87.4 & 85.1 & 88.8 \\
\hline
\end{tabular}

TABLE 1

Olivine Analyses ${ }^{\mathbf{a}}$

${ }^{\mathrm{a}}$ Normalized to four oxygens. 
TABLE 2

Spinel Analyses

\begin{tabular}{|c|c|c|c|}
\hline & $\begin{array}{l}332 \mathrm{~A}- \\
40-2, \\
57-63\end{array}$ & $\begin{array}{l}332 \mathrm{~B}- \\
29-1 \text {, } \\
63-66\end{array}$ & $\begin{array}{l}332 \mathrm{~B}- \\
29-1 \text {, } \\
63-66\end{array}$ \\
\hline $\mathrm{TiO}_{2}$ & 0.31 & 0.33 & 0.34 \\
\hline $\mathrm{Al}_{2} \mathrm{O}_{3}$ & 27.8 & 23.2 & 24.4 \\
\hline $\mathrm{Cr}_{2} \mathrm{O}_{3}$ & 38.9 & 44.0 & 42.3 \\
\hline $\mathrm{Fe}_{2} \mathrm{O}_{3}{ }^{\mathrm{a}}$ & 5.5 & 5.1 & 5.9 \\
\hline $\mathrm{FeO}$ & 12.3 & 12.1 & 10.8 \\
\hline $\mathrm{MnO}$ & 0.12 & 0.24 & 0.17 \\
\hline $\mathrm{MgO}$ & 16.0 & 15.5 & 16.6 \\
\hline$\Sigma$ & 100.9 & 100.4 & 100.5 \\
\hline $\mathrm{Ti}$ & 0.007 & 0.007 & 0.008 \\
\hline $\mathrm{Al}$ & 0.961 & 0.822 & 0.856 \\
\hline $\mathrm{Cr}$ & 0.903 & 1.048 & 0.996 \\
\hline $\mathrm{Fe}^{3+}$ & 0.122 & 0.115 & 0.133 \\
\hline $\mathrm{Fe}^{2+}$ & 0.302 & 0.305 & 0.268 \\
\hline $\mathrm{Mg}$ & 0.702 & 0.696 & 0.736 \\
\hline Mn & 0.003 & 0.006 & 0.004 \\
\hline
\end{tabular}

${ }^{\mathrm{a} C a l c u l a t e d}$ by assuming six oxygens and four cations.

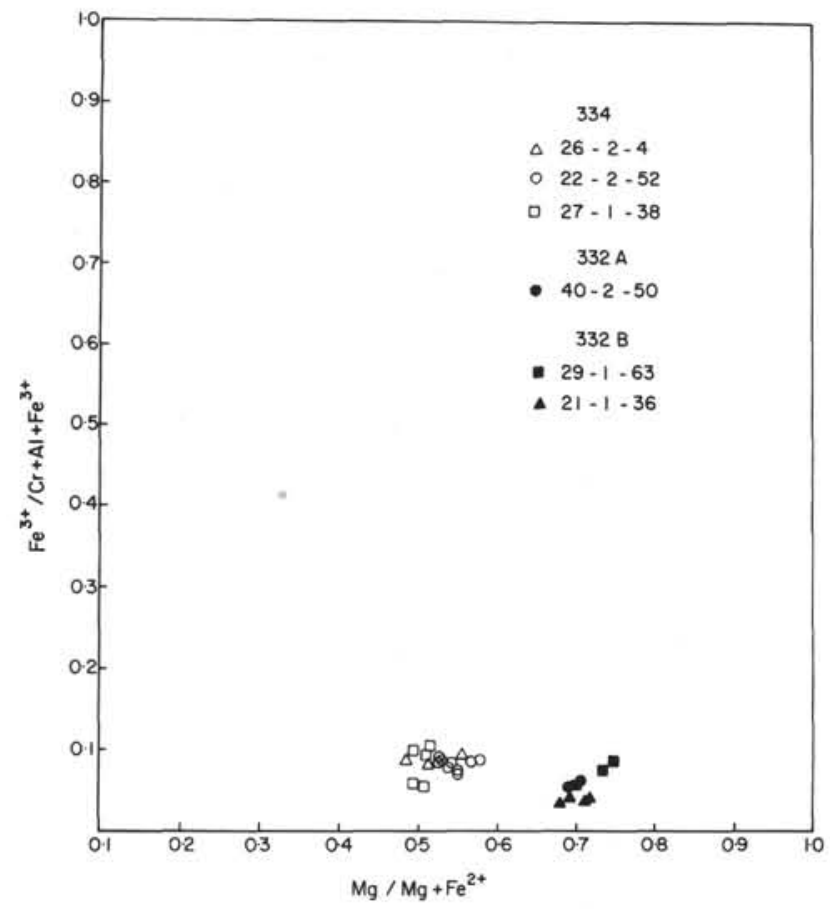

Figure 1(a). Plot of $\mathrm{Fe}^{3+} / \mathrm{Cr}+\mathrm{Al}+\mathrm{Fe}^{3+}$ versus $\mathrm{Mg} / \mathrm{Mg}+$ $\mathrm{Fe}^{2+}$ for analyzed spinels from Sites 332 and 334.

It is also interesting to note that the relative importance of these coupled substitutions changes with crystallization. The first pyroxenes that crystallized have all of these couples present including $\mathrm{R}^{2+} \mathrm{Cr}^{3+} \mathrm{SiAlO}_{6}$. However, $\mathrm{Cr}$ contents fall off rapidly with crystallization and thus this component disappears. The errors in our estimates of ferric iron are large and we have not identified any systematic variation of $\mathrm{Fe}^{3+}$ with $\mathrm{Fe}^{2+} / \mathrm{Fe}^{2+}+\mathrm{Mg}$. We do have evidence, however, that

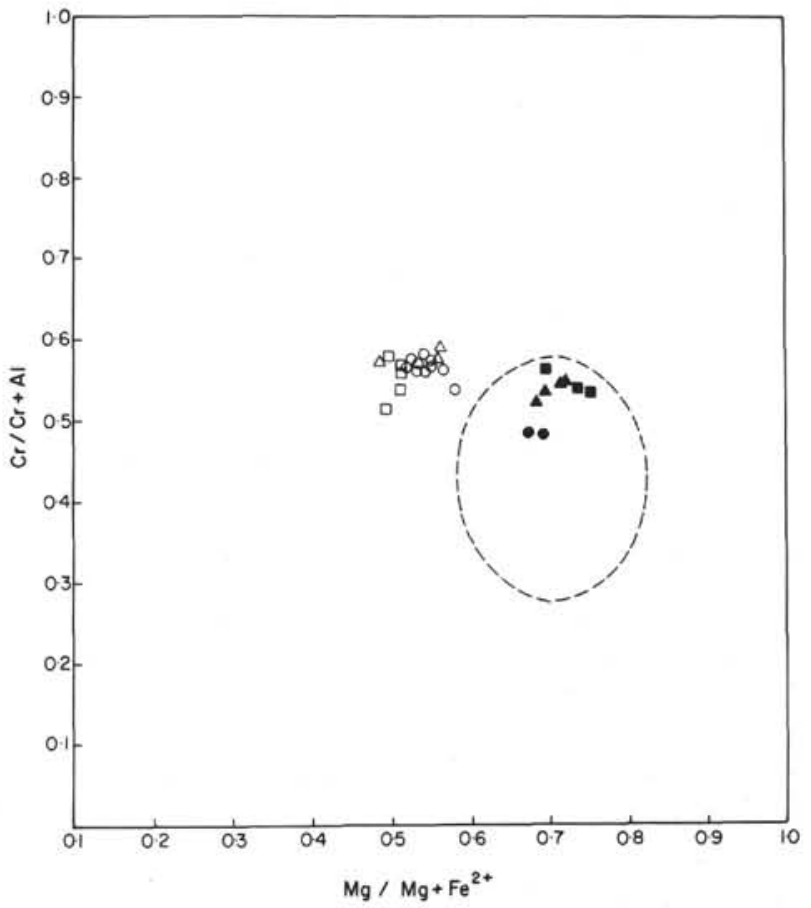

Figure 1(b). Plot of $\mathrm{Cr} / \mathrm{Cr}+\mathrm{Al}$ versus $\mathrm{Mg} / \mathrm{Mg}+\mathrm{Fe}^{2+}$ for analyzed spinels from Sites 332 and 334. Symbols are the same as in Figure 1a. Dashed line outlines compositions of spinels reported from oceanic tholeïtes.

$\mathrm{Al}$ VI decreases with $\mathrm{Fe}^{2+} / \mathrm{Fe}^{2+}+\mathrm{Mg}$. Thus the combined substitution ( $\mathrm{VIFe}^{3+}, \mathrm{VI} \mathrm{Al}$ ) - IV Al decreases with $\mathrm{Fe}^{2+} / \mathrm{Fe}^{2+}+\mathrm{Mg}$. The decrease in the above couples combined with a Ti buildup in the melt results in an increase in the $\mathrm{TiAl}_{2}$ component with increasing $\mathrm{Fe}^{2+} / \mathrm{Fe}^{2+}+\mathrm{Mg}$. This trend is clearly documented in pyroxene data presented in Table 3 . The overall sequence in pyroxene "others" components is nicely summarized in the $\mathrm{TiO}_{2}-\mathrm{Cr}_{2} \mathrm{O}_{3}-\mathrm{Al}_{2} \mathrm{O}_{3}$ ternary data display (Figure 6) where we see the initial importance of $\mathrm{Cr}_{2} \mathrm{O}_{3}$, then a trend toward $\mathrm{Al}_{2} \mathrm{O}_{3}$, and finally a relative increase in $\mathrm{TiO}_{2}$.

Plagioclase shows a relatively restricted compositional range (Figure 7, Table 4); most groundmass feldspar has a composition between 70 and 80 mole $\%$ An. Plagioclase with less than 70 mole \% An occurs principally in narrow zones adjacent to late-stage residuum and plagioclase with more than 80 mole \% An occurs principally within phenocrysts. A systematic decrease of $\mathrm{Fe} / \mathrm{Fe}+\mathrm{Mg}$ ratio with decreasing An content is illustrated in Figure 8.

Fine-grained clay minerals (smectite) or carbonate occur in minor amounts in most samples as vesicle filling or replacement of residual glass or mesostasis. Analysis of yellow "smectite" in Sample 332-2-5, 109 . $111 \mathrm{~cm}$ (Table 5) indicates that it is an "iron-rich saponite."

Potassium-rich zeolites (Plate 2, Figure 2), resembling phillipsite in bulk chemistry (Table 5), occur as aggregates of euhedral to subhedral crystals (to 0.05 $\mathrm{mm}$ ) filling fractures in Samples 332A-7-1, 37-39 cm and 332B-19-1, 107-110 cm. Similar zeolites fill vesicles 
TABLE 3

Pyroxene Analyses ${ }^{\mathrm{a}}$

\begin{tabular}{|c|c|c|c|c|c|c|c|c|c|}
\hline & $\begin{array}{c}332 \mathrm{~A}-7-1 \\
37-39\end{array}$ & $\begin{array}{c}332 \mathrm{~A}-7-1 \\
37-39\end{array}$ & $\begin{array}{c}332 \mathrm{~A}-34-2 \\
6-9\end{array}$ & $\begin{array}{c}332 \mathrm{~A}-40-2 \\
57-63\end{array}$ & $\begin{array}{c}332 \mathrm{~A}-40-2 \\
57-63\end{array}$ & $\begin{array}{c}332 \mathrm{~A}-40-2 \\
57-63\end{array}$ & $\begin{array}{c}332 \mathrm{~A}-40-2 \\
57-63\end{array}$ & $\begin{array}{c}332 A-40-2 \\
57-63\end{array}$ & $\begin{array}{c}332 \mathrm{~A}-40-2 \\
57-63\end{array}$ \\
\hline $\mathrm{SiO}_{2}$ & 50.94 & 51.01 & 51.05 & 52.36 & 53.82 & 52.55 & 51.97 & 48.56 & 48.58 \\
\hline $\mathrm{Al}_{2} \mathrm{O}_{3}$ & 4.46 & 3.11 & 4.86 & 3.29 & 1.25 & 3.25 & 2.22 & 2.65 & 2.44 \\
\hline $\mathrm{TiO}_{2}$ & 0.23 & 0.59 & 0.68 & 0.20 & 0.21 & 0.34 & 0.53 & 1.02 & 0.93 \\
\hline $\mathrm{Cr}_{2} \mathrm{O}_{3}$ & 1.57 & 0.00 & 0.65 & 1.04 & 0.05 & 0.10 & 0.00 & 0.00 & 0.00 \\
\hline "FeO" & 3.61 & 10.18 & 6.08 & 4.07 & 6.29 & 6.00 & 10.79 & 21.67 & 22.54 \\
\hline $\mathrm{MnO}$ & 0.00 & 0.22 & 0.12 & 0.11 & 0.21 & 0.14 & 0.28 & 0.46 & 0.48 \\
\hline $\mathrm{MgO}$ & 17.26 & 15.60 & 16.77 & 18.20 & 20.09 & 17.98 & 18.20 & 10.06 & 9.94 \\
\hline $\mathrm{CaO}$ & 21.13 & 18.96 & 20.02 & 21.42 & 18.13 & 19.57 & 15.39 & 15.92 & 15.20 \\
\hline $\mathrm{Na}_{2} \mathrm{O}$ & 0.05 & 0.07 & 0.19 & 0.15 & 0.08 & 0.10 & 0.14 & 0.17 & 0.14 \\
\hline$\Sigma$ & 99.25 & 99.74 & 100.42 & 100.84 & 100.13 & 100.03 & 99.52 & 100.51 & 100.25 \\
\hline $\mathrm{FeO}$ & 3.06 & 8.89 & 5.12 & 2.10 & 4.93 & 5.42 & 9.53 & 19.40 & 20.60 \\
\hline $\mathrm{Fe}_{2} \mathrm{O}_{3}$ & 0.62 & 1.44 & 1.07 & 2.18 & 1.51 & 0.64 & 1.40 & 2.52 & 2.15 \\
\hline New $\Sigma$ & 99.32 & 99.89 & 100.53 & 101.05 & 100.28 & 100.09 & 99.66 & 100.76 & 100.46 \\
\hline $\mathrm{Si}$ & 1.868 & 1.898 & 1.860 & 1.886 & 1.949 & 1.914 & 1.922 & 1.880 & 1.891 \\
\hline $\mathrm{Al}^{\mathrm{IV}}$ & 0.132 & 0.102 & 0.140 & 0.114 & 0.051 & 0.086 & 0.078 & 0.120 & 0.109 \\
\hline$\Sigma$ Tet & 2.000 & 2.000 & 2.000 & 2.000 & 2.000 & 2.000 & 2.000 & 2.000 & 2.000 \\
\hline $\mathrm{Ti}$ & 0.006 & 0.017 & 0.019 & 0.005 & 0.006 & 0.009 & 0.015 & 0.030 & 0.027 \\
\hline $\mathrm{Al}^{\mathrm{VI}}$ & 0.061 & 0.034 & 0.068 & 0.025 & 0.002 & 0.054 & 0.019 & 0.000 & 0.002 \\
\hline $\mathrm{Cr}$ & 0.046 & 0.000 & 0.019 & 0.030 & 0.001 & 0.003 & 0.000 & 0.000 & 0.000 \\
\hline $\mathrm{Fe}^{3+}$ & 0.017 & 0.040 & 0.029 & 0.059 & 0.041 & 0.018 & 0.039 & 0.073 & 0.063 \\
\hline $\mathrm{Fe}^{2+}$ & 0.094 & 0.276 & 0.156 & 0.063 & 0.149 & 0.165 & 0.295 & 0.628 & 0.670 \\
\hline $\mathrm{Mn}$ & 0.000 & 0.007 & 0.004 & 0.003 & 0.006 & 0.004 & 0.009 & 0.015 & 0.016 \\
\hline $\mathrm{Mg}$ & 0.943 & 0.865 & 0.910 & 0.977 & 1.084 & 0.976 & 1.003 & 0.580 & 0.576 \\
\hline$\Sigma$ Oct & 1.167 & 1.239 & 1.205 & 1.162 & 1.289 & 1.229 & 1.380 & 1.326 & 1.354 \\
\hline $\mathrm{Ca}$ & 0.830 & 0.756 & 0.781 & 0.827 & 0.704 & 0.764 & 0.610 & 0.660 & 0.634 \\
\hline $\mathrm{Na}$ & 0.004 & 0.005 & 0.013 & 0.010 & 0.006 & 0.007 & 0.010 & 0.013 & 0.011 \\
\hline$\Sigma$ Total Cations & 4.001 & 4.000 & 3.999 & 3.999 & 3.999 & 4.000 & 4.000 & 3.999 & 3.999 \\
\hline Quad & 86.8 & 89.8 & 86.0 & 88.1 & 94.9 & 91.4 & 92.2 & 88.0 & 89.1 \\
\hline Other & 13.2 & 10.2 & 14.0 & 11.9 & 5.1 & 8.6 & 7.8 & 12.0 & 10.9 \\
\hline \multicolumn{10}{|l|}{ Breakdown of Quad } \\
\hline $\mathrm{Ca}$ & 44.5 & 39.8 & 42.3 & 44.3 & 36.3 & 40.1 & 32.0 & 35.3 & 33.7 \\
\hline $\mathrm{Mg}$ & 50.5 & 45.6 & 49.3 & 52.3 & 56.0 & 51.2 & 52.6 & 31.1 & 30.7 \\
\hline $\mathrm{Fe}^{2+}$ & 5.0 & 14.6 & 8.4 & 3.4 & 7.7 & 8.7 & 15.5 & 33.6 & 35.6 \\
\hline \multicolumn{10}{|l|}{ Breakdown of others } \\
\hline $\mathrm{Ti}$ & 4.5 & 13.3 & 10.8 & 4.2 & 9.2 & 9.1 & 14.4 & 18.2 & 18.5 \\
\hline $\mathrm{NaM} 2$ & 2.5 & 4.1 & 7.8 & 8.0 & 9.0 & 6.9 & 9.8 & 7.8 & 7.2 \\
\hline $\mathrm{Al}^{\mathrm{IV}}$ & 93.0 & 82.6 & 81.4 & 87.8 & 81.8 & 84.0 & 75.8 & 73.9 & 74.3 \\
\hline Best name for others & CaAl-CATS & $\mathrm{CaFe}^{3+}$-CATS & CaAl-CATS & $\mathrm{CaFe}^{3+}$-CATS & $\mathrm{CaFe}^{3+}$-CATS & CaAl-CATS & $\mathrm{CaFe}^{3+}-\mathrm{CATS}$ & $\mathrm{CaFe}^{2+}-\mathrm{TAL}$ & $\mathrm{CaFe}^{2+}-\mathrm{TAL}$ \\
\hline $\mathrm{Fe}^{2+} / \mathrm{Fe}^{2+}+\mathrm{Mg}$ & 0.09 & 0.24 & 0.15 & 0.06 & 0.12 & 0.14 & 0.23 & $" 0.52$ & 0.54 \\
\hline
\end{tabular}

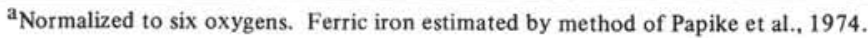

adjacent to the fractures; however, there is very little alteration associated with the fractures; fragments of olivine, completely surrounded by zeolite, show only narrow alteration rims. The presence of the zeolites and the general lack of alteration possibly indicate the existence of relatively cool, silica and alkali-rich basic solutions high in the oceanic crust and have interesting implications concerning the chemical interaction between oceanic crust and seawater (i.e., Mottl et al., 1974). Vesicles in more altered portions of Sample $332 \mathrm{~A}-7-1,37-39 \mathrm{~cm}$ are partly filled with what is apparently hydrated $\mathrm{Mn}$-oxide $(\mathrm{Fe} / \mathrm{Mn}=0.04)$ which contains $10 \mathrm{wt} \% \mathrm{MgO}$. The high $\mathrm{MgO}$ content is difficult to explain in terms of known solid solutions and may indicate a submicroscopic intergrowth of several phases.

\section{SITE 334}

Drilling at Site 334 unexpectedly encountered coarsegrained gabbros and ultramafic rocks beneath a thin layer $(60.5 \mathrm{~m})$ of fine-grained basalt. Mafic and ultramafic rock units are separated by brecciated (shear) zones and represent a mechanical juxtaposition of rock types. Primary phase layering, if present in the material recovered, is relatively obscure.

Preliminary examination indicates that the coarsegrained rocks are principally two-pyroxene gabbros \pm olivine and serpentinized lherzolitic peridotites. Relict textures within the peridotites indicate that they were primary olivine, chromite cumulates with intercumulus pyroxene and plagioclase. Relative "primary" mineral abundances within peridotites are:

$$
\text { ol }>\text { cpx }>\text { opx }>\text { chr }>\text { plag. }
$$

Pargasitic amphibole present within some peridotite samples is probably not a primary phase, but represents retrograde reaction of primary peridotite mineralogy at pressure and temperatures greater than those at which serpentinization occurred. Textural evidence indicates that the gabbros are principally pyroxeneplagioclase accumulates (Wager et al., 1960). Olivine and olivine pseudomorphs within olivine gabbros are anhedral and rounded, indicating that olivine did not 
TABLE 3 - Continued

\begin{tabular}{|c|c|c|c|c|c|c|c|c|c|}
\hline & $\begin{array}{l}332 \mathrm{~B}-2-5 \\
109-111\end{array}$ & $\begin{array}{c}332 \mathrm{~B}-2-5 \\
109-111\end{array}$ & $\begin{array}{c}332 \mathrm{~B}-2-5, \\
109-111\end{array}$ & $\begin{array}{c}332 \mathrm{~B}-2-5, \\
109-111\end{array}$ & $\begin{array}{l}\text { 332B-2-5, } \\
109-111\end{array}$ & $\begin{array}{l}332 \mathrm{~B}-2-5 \\
109-111\end{array}$ & $\begin{array}{c}\text { 332B-19-1, } \\
107-111\end{array}$ & $\begin{array}{c}332 \mathrm{~B}-29-1 \\
63-66\end{array}$ & $\begin{array}{c}332 \mathrm{~B}-29-1 \text {, } \\
63-66\end{array}$ \\
\hline $\mathrm{SiO}_{2}$ & 50.36 & 51.10 & 50.49 & 48.90 & 48.11 & 47.67 & 50.72 & 50.17 & 50.76 \\
\hline $\mathrm{Al}_{2} \mathrm{O}_{3}$ & 5.11 & 3.47 & 2.37 & 1.86 & 2.40 & 2.10 & 2.84 & 3,42 & 3.18 \\
\hline $\mathrm{TiO}_{2}$ & 0.66 & 0.46 & 0.55 & 0.68 & 1.15 & 0.83 & 0.74 & 0.65 & 0.67 \\
\hline $\mathrm{Cr}_{2} \mathrm{O}_{3}$ & 0.18 & 0.10 & 0.00 & 0.00 & 0.00 & 0.00 & 0.08 & 0.21 & 0.21 \\
\hline "FeO" & 5.64 & 7.23 & 15.27 & 22.82 & 22.42 & 25.25 & 12.55 & 9.32 & 9.96 \\
\hline $\mathrm{MnO}$ & 0.04 & 0.13 & 0.30 & 0.42 & 0.50 & 0.56 & 0.22 & 0.21 & 0.13 \\
\hline $\mathrm{MgO}$ & 15.96 & 16.21 & 15.91 & 12.96 & 10.51 & 8.61 & 14.33 & 14.50 & 14.79 \\
\hline $\mathrm{CaO}$ & 21.84 & 20.65 & 14.43 & 10.72 & 14.18 & 14.07 & 18.73 & 21.66 & 20.05 \\
\hline $\mathrm{Na}_{2} \mathrm{O}$ & 0.07 & 0.04 & 0.03 & 0.01 & 0.16 & 0.00 & 0.11 & 0.09 & 0.08 \\
\hline$\Sigma$ & 99.86 & 99.39 & 99.35 & 98.37 & 99.43 & 99.09 & 100.32 & 100.23 & 99.83 \\
\hline $\mathrm{FeO}$ & 4.02 & 5.85 & 13.58 & 21.78 & 20.73 & 23.81 & 11.05 & 6.35 & 8.75 \\
\hline $\mathrm{Fe}_{2} \mathrm{O}_{3}$ & 1.80 & 1.53 & 1.87 & 1.16 & 1.87 & 1.60 & 1.67 & 3.30 & 1.34 \\
\hline New $\Sigma$ & 100.04 & 99.54 & 99.53 & 98.49 & 99.61 & 99.25 & 100.49 & 100.56 & 99.96 \\
\hline $\mathrm{Si}$ & 1.846 & 1.890 & 1.906 & 1.920 & 1.886 & 1.902 & 1.896 & 1.861 & 1.892 \\
\hline $\mathrm{Al}^{\mathrm{IV}}$ & 0.154 & 0.110 & 0.094 & 0.080 & 0.111 & 0.098 & 0.104 & 0.139 & 0.108 \\
\hline$\Sigma$ Tet & 2.000 & 2.000 & 2.000 & 2.000 & 1.997 & 2.000 & 2.000 & 2.000 & 2.000 \\
\hline $\mathrm{Ti}$ & 0.018 & 0.013 & 0.016 & 0.020 & 0.034 & 0.025 & 0.021 & 0.018 & 0.019 \\
\hline $\mathrm{Al}^{\mathrm{VI}}$ & 0.067 & 0.042 & 0.012 & 0.006 & 0.000 & 0.000 & 0.021 & 0.011 & 0.032 \\
\hline $\mathrm{Cr}$ & 0.005 & 0.003 & 0.000 & 0.000 & 0.000 & 0.000 & 0.002 & 0.006 & 0.006 \\
\hline $\mathrm{Fe}^{3+}$ & 0.050 & 0.043 & 0.053 & 0.034 & 0.055 & 0.048 & 0.047 & 0.092 & 0.038 \\
\hline $\mathrm{Fe}^{2+}$ & 0.123 & 0.181 & 0.429 & 0.715 & 0.680 & 0.794 & 0.345 & 0.197 & 0.273 \\
\hline Mn & 0.001 & 0.004 & 0.010 & 0.014 & 0.017 & 0.019 & 0.007 & 0.007 & 0.004 \\
\hline $\mathrm{Mg}$ & 0.872 & 0.894 & 0.895 & 0.758 & 0.614 & 0.512 & 0.798 & 0.802 & 0.822 \\
\hline$\Sigma$ Oct & 1.136 & 1.180 & 1.415 & 1.547 & 1.400 & 1.398 & 1.241 & 1.133 & 1.194 \\
\hline $\mathrm{Ca}$ & 0.858 & 0.818 & 0.584 & 0.451 & 0.596 & 0.601 & 0.750 & 0.861 & 0.801 \\
\hline $\mathrm{Na}$ & 0.005 & 0.003 & 0.002 & 0.001 & 0.012 & 0.000 & 0.008 & 0.006 & 0.006 \\
\hline$\Sigma$ Total cations & 3.999 & 4.001 & 4.001 & 3.999 & 4.005 & 3.999 & 3.999 & 4.000 & 4.001 \\
\hline Quad & 84.6 & 89.0 & 90.6 & 92.0 & 88.9 & 90.2 & 89.6 & 86.1 & 98.2 \\
\hline Other & 15.4 & 11.0 & 9.4 & 8.0 & 11.1 & 9.8 & 10.4 & 13.9 & 10.8 \\
\hline \multicolumn{10}{|l|}{ Breakdown of quad } \\
\hline $\mathrm{Ca}$ & 46.3 & 43.2 & 30.6 & 23.4 & 31.5 & 31.5 & 39.6 & 46.3 & 42.3 \\
\hline $\mathrm{Mg}$ & 47.1 & 47.2 & 46.9 & 39.4 & 32.5 & 26.8 & 42.2 & 43.1 & 43.4 \\
\hline $\mathrm{Fe}^{2+}$ & 6.7 & 9.6 & 22.5 & 37.2 & 36.0 & 41.6 & 18.2 & 10.6 & 14.4 \\
\hline \multicolumn{10}{|l|}{ Breakdown of others } \\
\hline $\mathrm{Ti}$ & 10.3 & 10.2 & 14.0 & 19.9 & 21.6 & 20.2 & 15.7 & 11.1 & 14.2 \\
\hline $\mathrm{NaM} 2$ & 2.8 & 2.3 & 2.0 & 0.8 & 7.7 & 0.0 & 6.0 & 4.0 & 4.4 \\
\hline $\mathrm{Al}^{\mathrm{IV}}$ & $\begin{array}{c}86.9 \\
\text { Cal-CATS }\end{array}$ & 87.5 & 84.1 & 79.3 & $\begin{array}{c}70: 7 \\
\text { (n) }\end{array}$ & $\begin{array}{l}79.8 \\
\mathrm{CaFe}^{2+}\end{array}$ & 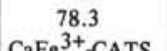 & $\begin{array}{l}84.9 \\
\end{array}$ & 81.4 \\
\hline $\begin{array}{l}\text { Best name for others } \\
\mathrm{Fe}^{2+} / \mathrm{Fe}^{2+}+\mathrm{Mg}\end{array}$ & $\begin{array}{c}\text { CaAl-CATS } \\
0.12\end{array}$ & $\begin{array}{c}\mathrm{CaFe}^{3+} \text {-CATS } \\
0.17\end{array}$ & $\begin{array}{c}\mathrm{CaFe}^{3+} \text {-CATS } \\
0.32\end{array}$ & $\begin{array}{c}\mathrm{Mg}-\mathrm{TAL} \\
0.49\end{array}$ & $\begin{array}{c}\mathrm{CaFe}^{2+}-\mathrm{TAL} \\
0.53\end{array}$ & $\begin{array}{c}\mathrm{CaFe}^{2+} \cdot \mathrm{TAL} \\
0.61\end{array}$ & $\begin{array}{c}\mathrm{CaFe}^{3+}-\mathrm{CATS} \\
0.30\end{array}$ & $\begin{array}{c}\mathrm{CaFe}^{3+}-\mathrm{CATS} \\
0.20\end{array}$ & $\begin{array}{c}\mathrm{CaFe}^{3+} \text {-CATS } \\
0.25\end{array}$ \\
\hline
\end{tabular}

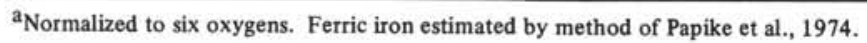

grow from the intercumulus melt and possibly was reacting with the melt. Chromite is present in small but variable amounts in the olivine gabbros, but is absent in the one sample of olivine-free gabbro available for study. Sulfides, present in trace amounts throughout the samples, are predominantly iron sulfides; however, within the gabbros some globules contain complex intergrowths of $\mathrm{Fe}, \mathrm{Cu}$, and $\mathrm{Ni}$ sulfides. The most probable origin for the sulfide masses is as an immiscible sulfide liquid in a differentiating basaltic magma (Skinner and Peck, 1969). The degree of alteration within the samples is a direct function of the olivine content. Olivine-free gabbros are relatively unaltered whereas olivine gabbros are severely altered only in the vicinity of olivine and olivine pseudomorphs. Apparently olivine altered with relative ease, and its alteration products were much more permeable to fluids than the interlocking framework of pyroxene and plagioclase.

Strain features including kink bands within olivine, curved twin lamellae within plagioclase, and deformed and offset exsolution lamellae within pyroxene are pres- ent but of minor importance in the samples studied. In all cases the strain features appear to have developed late in the history of the rocks.

Primary-pyroxene compositions for the peridotites and gabbros, determined by broad-beam electron microprobe analysis (Figure 9), fall inside of the trends (solvus) defined by pyroxenes from the Bushveld and other large layered intrusions, indicating a higher crystallization temperature for the Site 334 pyroxenes. The slightly anomalous compositions for Samples 334$22-2,52-55 \mathrm{~cm}$ and $334-24-3,55-58 \mathrm{~cm}$ are probably a result of alteration but may also be an indication that all of the coarse-grained samples are not strictly comagmatic.

Primary low-calcium pyroxenes in all samples studied are of the Bushveld type with thin exsolution lamellae of augite parallel to (100), indicating primary crystallization as orthopyroxene (Hess, 1941). Augites in peridotites and olivine gabbros have exsolved orthopyroxene parallel to (100), consistent with the exsolution pattern observed in the orthopyroxenes (Plate 2 , Figure 3). In olivine-free gabbro $(334-21-1,36-47 \mathrm{~cm})$ 


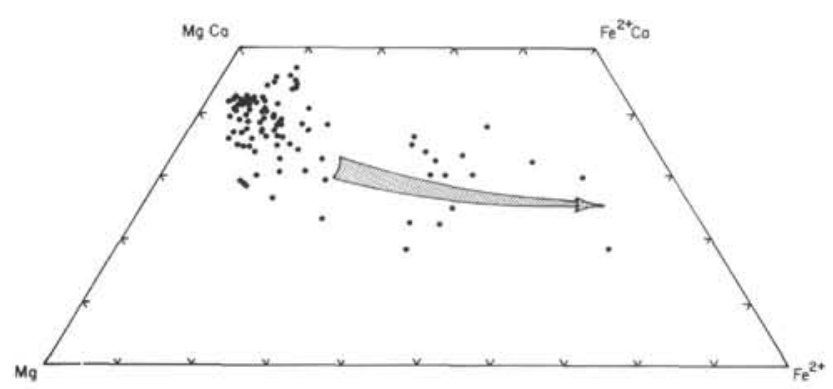

Figure 2. Pyroxene analyses (Site 332) plotted on pyroxene quadrilateral. Arrow indicates iron-enrichment trend.

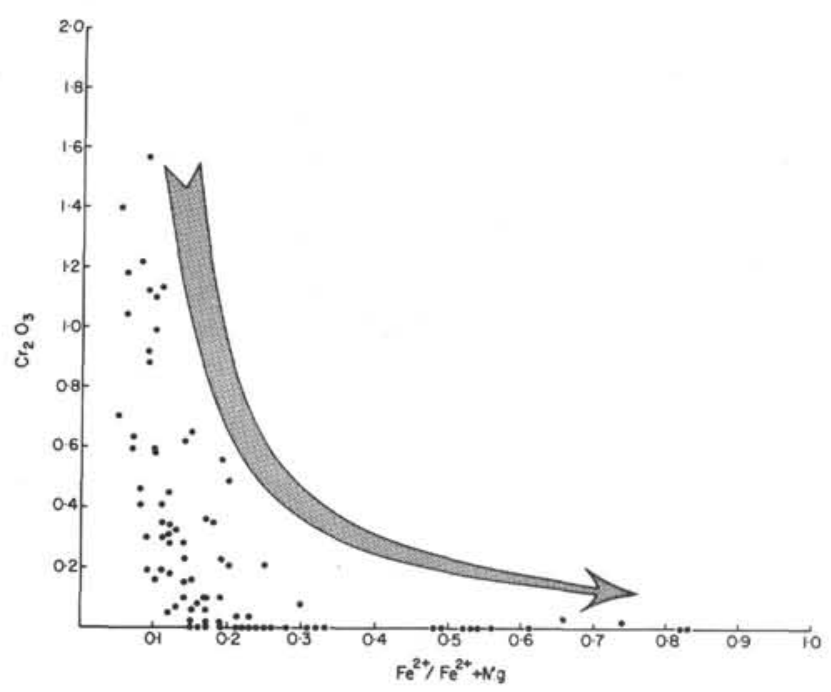

Figure 3. Plot of $\mathrm{Cr}_{2} \mathrm{O}_{3}(w t \%)$ versus $\mathrm{Fe}^{2+} / \mathrm{Fe}^{2+}+\mathrm{Mg}$ for pyroxenes (Site 332). Arrow indicates general cyrstallization trend.

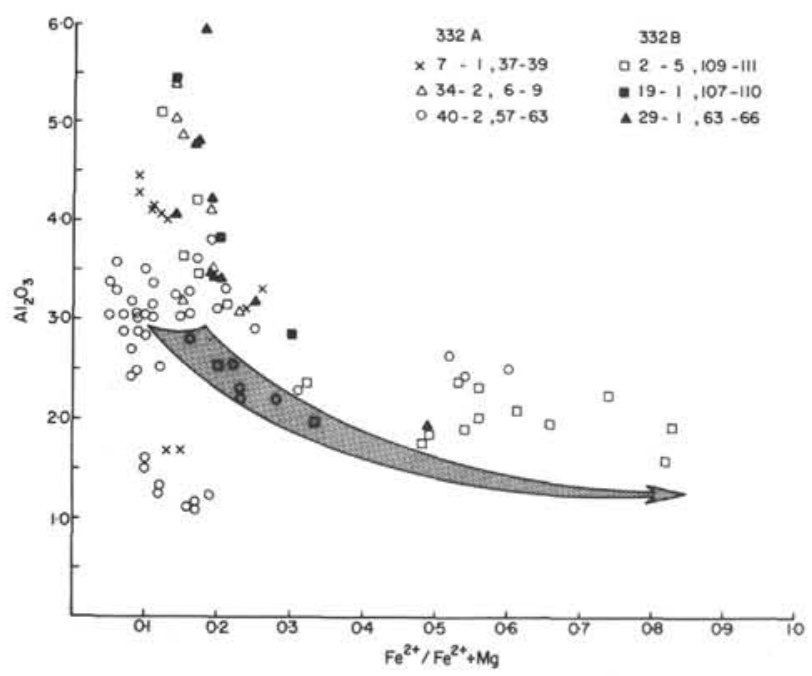

Figure 4. Plot of $\mathrm{Al}_{2} \mathrm{O}_{3}(w t \%)$ versus $\mathrm{Fe}^{2+} / \mathrm{Fe}^{2+}+\mathrm{Mg}$ for pyroxenes (Site 332). Arrow indicates general crystallization trend.

the augite exhibits a complex exsolution pattern (Plate 2 , Figure 4) with at least two sets of low-calcium pyroxene lamellae parallel to (001) and one set parallel to

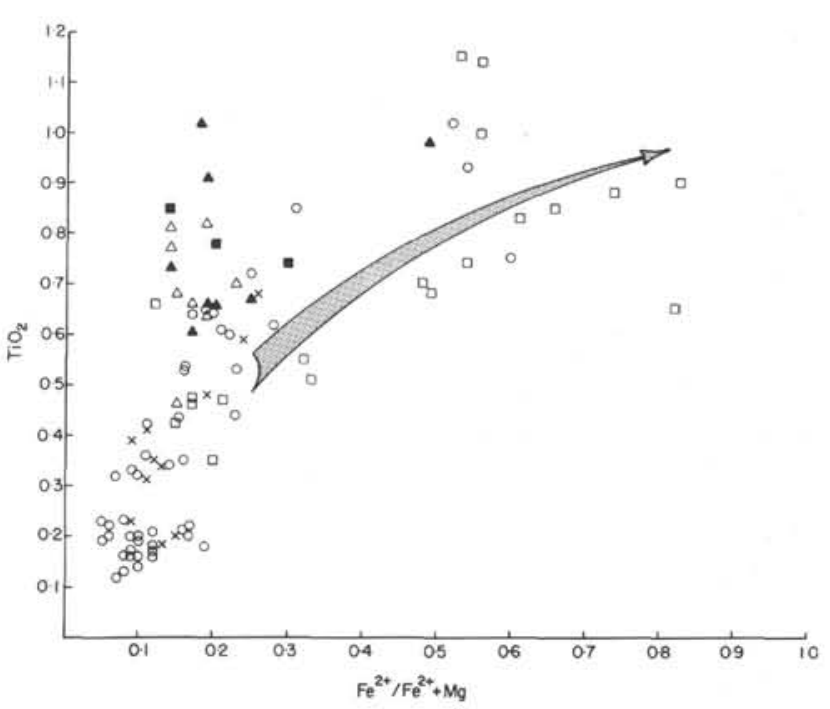

Figure 5. Plot of $\mathrm{TiO}_{2}(w t \%)$ versus $\mathrm{Fe}^{2+} / \mathrm{Fe}^{2+}+\mathrm{Mg}$ for pyroxenes (Site 332). Arrow indicates general cyrstallization trend. Symbols are same as in Figure 4.

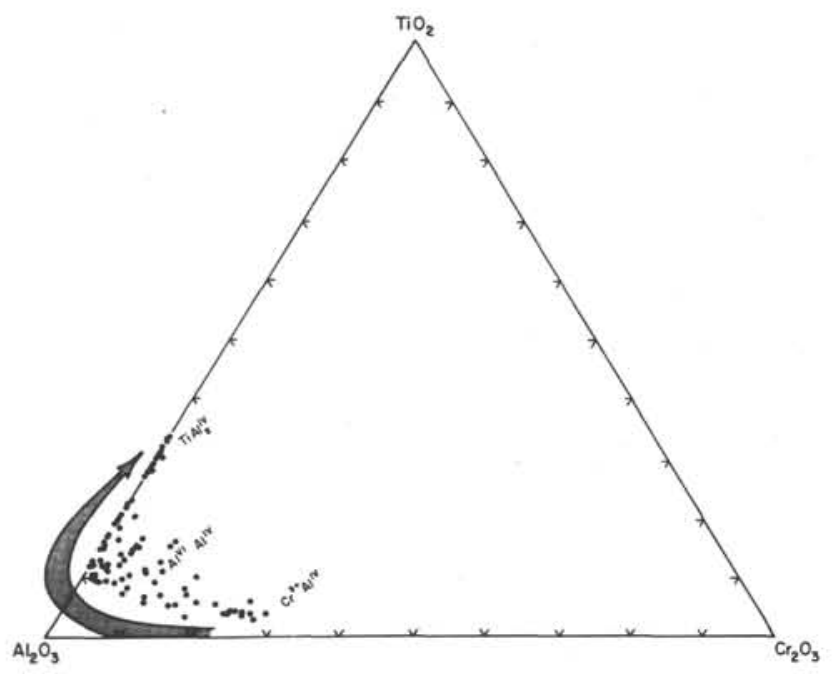

Figure 6. Ternary plot of $\mathrm{TiO}_{2}-\mathrm{Al}_{2} \mathrm{O}_{3} \mathrm{Cr}_{2} \mathrm{O}_{3}$ (wt \%) for pyroxenes (Site 332). Arrow indicates general cyrstallization trend and important "other" components are indicated along the crystallization path.

(100). Optically the (001) lamellae appear to consist of both pigeonite and orthopyroxene; however, singlecrystal X-ray diffraction data on separated crystals indicate that both pigeonite and orthopyroxene are oriented with their (100) planes in common with the augite host. The complex exsolution features within these clinopyroxenes are presently subject to detailed investigation.

The presence of broad exsolution lamellae parallel to (001) indicating initial exsolution as pigeonite in augites from olivine-free gabbro 334-21-1, 36-47 cm presents an interesting problem. Why would an augite, coexisting with a primary orthopyroxene $\left(\mathrm{Fe}_{\text {tot }} / \mathrm{Fe}_{\text {tot }}+\mathrm{Mg}\right.$ ratio $=0.24$ ) exsolve pigeonite instead of orthopyroxene as might be expected?

Possible explanations for these phenomena include: (1) the (001) pigeonite crystallized on the metastable ex- 


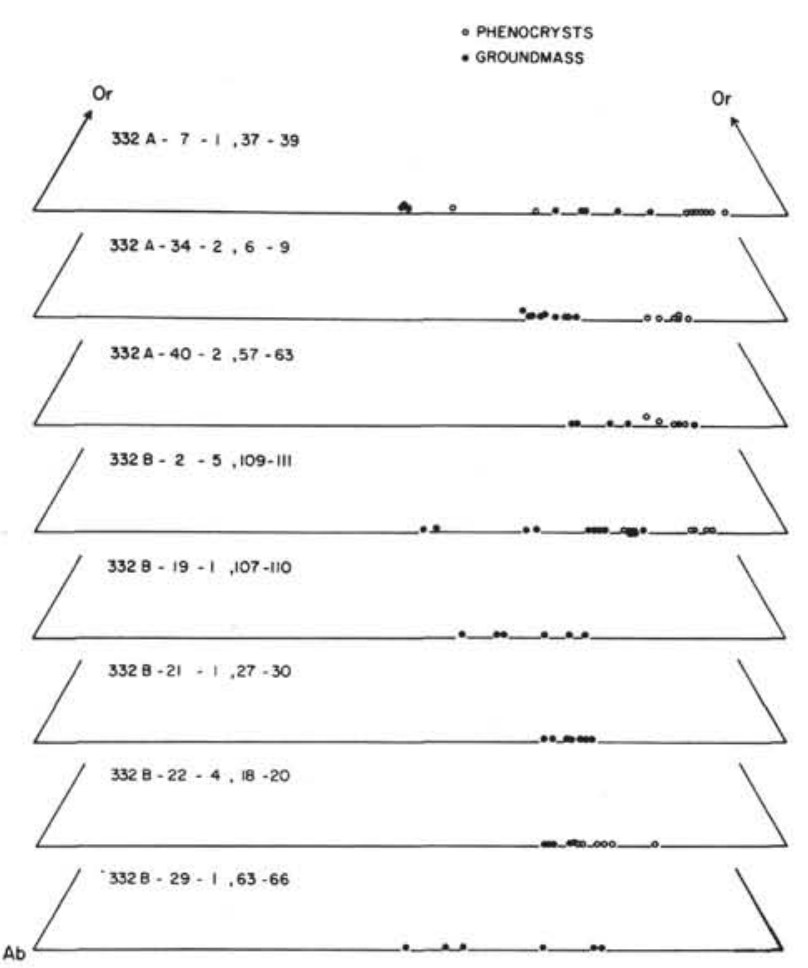

Figure 7. Ternary plot of $\mathrm{Or}-A b-A n$ end members for plagioclases (Site 332).

tension of the augite-pigeonite solvus, (2) the gabbro was crystallizing just inside of the augite-pigeonite- orthopyroxene three-phase region, and we have not identified the inverted pigeonite, or (3) the low-calcium pyroxene crystallized principally from the intercumulus liquid, allowing augite to crystallize above and orthopyroxene to crystallize below the inversion curve very near the transition. Hess (1960) reports that in the Stillwater complex, where orthopyroxene crystallized early and in great abundance, the first appearance of augite with pigeonite exsolution occurred higher in the stratigraphic section than the first occurrence of primary pigeonite.

Average electron microprobe analyses of exsolution lamellae and augite host are shown in Figure 10. The average for olivine-free gabbro $334-21-1,36-47 \mathrm{~cm}$ includes points on all three sets of exsolution lamellae, which within the error of microprobe analyses have the same composition. Only analyses of augite host are shown for peridotite Sample 334-22-2, 52-55 cm; very narrow lamellae, coupled with alteration, preclude analysis of the exsolved phase. The average analysis generally falls outside of the $810^{\circ}$ solvus of Lindsley et al. (1974), indicating equilibration to extremely low temperatures; however, the temperatures implied must be interpreted with caution because of the unknown effect of nonquadrilateral components upon the position of the pyroxene solvus.

Olivine shows very little compositional variation within samples, ranging from 88.0 to 88.4 mole \% Fo in peridotite $(334-22-2,52-55 \mathrm{~cm})$ and from 85.7 to 86.5 mole \% Fo in olivine gabbro $(334-27-1,38-50 \mathrm{~cm})$. Olivine contains between 0.03 and 0.06 wt $\% \mathrm{CaO}$ in both samples and $\mathrm{MnO}$ ranges from 0.08 to $0.5 \mathrm{wt} \%$ ir

TABLE 4

Plagioclase Analyses ${ }^{\mathrm{a}}$

\begin{tabular}{|c|c|c|c|c|c|c|c|c|c|c|}
\hline & 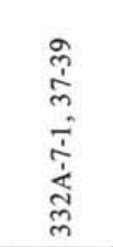 & 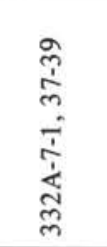 & 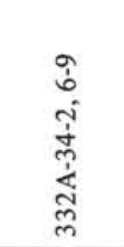 & 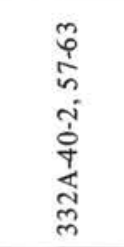 & 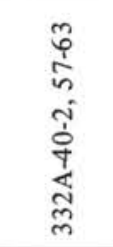 & 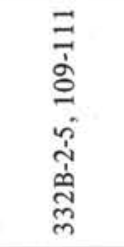 & 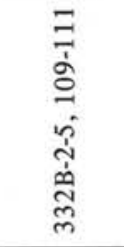 & 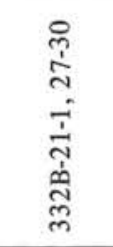 & 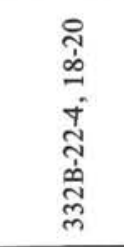 & 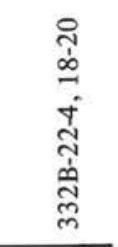 \\
\hline $\mathrm{SiO}_{2}$ & 46.4 & 51.4 & 50.5 & 50.2 & 46.6 & 55.1 & 45.9 & 50.8 & 49.4 & 50.2 \\
\hline $\mathrm{Al}_{2} \mathrm{O}_{3}$ & 33.8 & 29.7 & 31.0 & 31.1 & 33.7 & 27.8 & 34.8 & 30.2 & 33.1 & 31.2 \\
\hline $\mathrm{FeO}^{*}$ & 0.39 & 0.88 & 0.85 & 0.62 & 0.47 & 0.41 & 0.32 & 1.00 & 0.44 & 0.81 \\
\hline $\mathrm{MgO}$ & 0.28 & 0.22 & 0.35 & 0.27 & 0.20 & 0.12 & 0.24 & 0.69 & 0.21 & 0.32 \\
\hline $\mathrm{CaO}$ & 17.8 & 13.5 & 14.5 & 14.6 & 17.4 & 11.0 & 17.7 & 14.4 & 14.7 & 14.5 \\
\hline $\mathrm{Na}_{2} \mathrm{O}$ & 1.33 & 3.74 & 3.10 & 3.18 & 1.53 & 5.3 & 1.07 & 2.90 & 2.62 & 3.10 \\
\hline $\mathrm{K}_{2} \mathrm{O}$ & 0.01 & 0.06 & 0.07 & 0.04 & 0.04 & 0.09 & nil & 0.02 & nil & 0.04 \\
\hline$\Sigma$ & 99.9 & 99.5 & 100.3 & 100.3 & 99.9 & 100.8 & 100.1 & 99.9 & 100.5 & 100.2 \\
\hline $\mathrm{Si}$ & 2.137 & 2.356 & 2.300 & 2.299 & 2.148 & 2.481 & 2.111 & 2.321 & 2.241 & 2.293 \\
\hline $\mathrm{Al}$ & 1.836 & 1.607 & 1.664 & 1.671 & 1.830 & 1.474 & 1.888 & 1.627 & 1.772 & 1.676 \\
\hline $\mathrm{Fe}^{*}$ & 0.015 & 0.034 & 0.032 & 0.024 & 0.018 & 0.050 & 0.012 & 0.038 & 0.017 & 0.031 \\
\hline $\mathrm{Mg}$ & 0.019 & 0.015 & 0.024 & 0.018 & 0.014 & 0.008 & 0.016 & 0.047 & 0.015 & 0.022 \\
\hline $\mathrm{Ca}$ & 0.879 & 0.661 & 0.709 & 0.711 & 0.859 & 0.532 & 0.870 & 0.704 & 0.713 & 0.709 \\
\hline $\mathrm{Na}$ & 0.119 & 0.332 & 0.274 & 0.281 & 0.136 & 0.466 & 0.095 & 0.257 & 0.231 & 0.275 \\
\hline K & 0.001 & 0.004 & 0.001 & 0.002 & 0.002 & 0.005 & - & 0.001 & - & 0.002 \\
\hline $\mathrm{Fe}^{*} / \mathrm{Fe}^{*}+\mathrm{Mg}$ & 0.441 & 0.693 & 0.578 & 0.564 & 0.573 & 0.860 & 0.429 & 0.449 & 0.536 & 0.588 \\
\hline An & 88.0 & 66.3 & 71.8 & 71.5 & 86.1 & 53.0 & 90.1 & 73.2 & 75.5 & 71.9 \\
\hline $\mathrm{Ab}$ & 11.9 & 33.3 & 27.8 & 28.3 & 13.7 & 46.5 & 9.9 & 26.7 & 24.5 & 27.8 \\
\hline Or & 0.1 & 0.4 & 0.4 & 0.2 & 0.2 & 0.5 & 0.0 & 0.1 & 0.0 & 0.3 \\
\hline
\end{tabular}

${ }^{\mathrm{a}}$ Normalized to eight oxygens. 


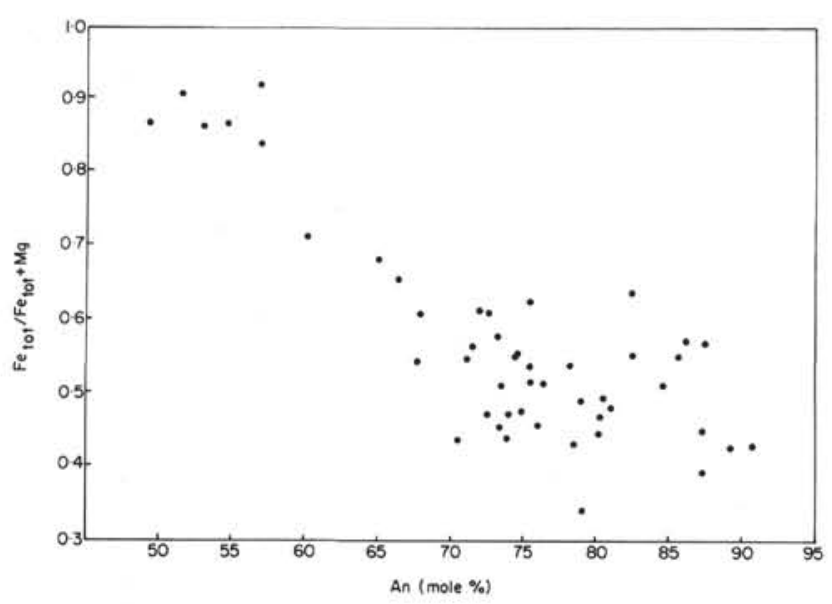

Figure 8. Plot of $\mathrm{Fe}_{\text {tot }} / \mathrm{Fe}_{\text {tot }}+\mathrm{Mg}$ versus mole \% An for plagioclases (Site 332).

TABLE 5

Alteration Products

\begin{tabular}{|c|c|c|c|}
\hline & $\begin{array}{c}37-332 \mathrm{~B}- \\
19-1, \\
107-110\end{array}$ & $\begin{array}{c}37-332 \mathrm{~A}- \\
7-1, \\
37-39\end{array}$ & $\begin{array}{c}37-332 \mathrm{~B}- \\
2-5, \\
109-111\end{array}$ \\
\hline $\mathrm{SiO}_{2}$ & $59.8^{\mathrm{a}}$ & $58.4^{\mathrm{b}}$ & $49.7^{\mathrm{c}}$ \\
\hline $\mathrm{TiO}_{2}$ & n.d. & n.d. & 0.02 \\
\hline $\mathrm{Al}_{2} \mathrm{O}_{3}$ & 20.3 & 20.5 & 6.0 \\
\hline $\mathrm{FeO}^{*}$ & 0.07 & 0.06 & 10.0 \\
\hline $\mathrm{MnO}$ & n.d. & n.d. & 0.03 \\
\hline $\mathrm{MgO}$ & nil & nil & 22.6 \\
\hline $\mathrm{CaO}$ & 0.27 & 0.41 & 0.95 \\
\hline $\mathrm{Na}_{2} \mathrm{O}$ & 5.2 & 4.41 & 0.03 \\
\hline $\mathrm{K}_{2} \mathrm{O}$ & 7.2 & 7.3 & 0.39 \\
\hline$\Sigma$ & 92.9 & 91.2 & 89.7 \\
\hline $\begin{array}{l}\text { No. of } \\
\text { oxygens }\end{array}$ & 16 & 16 & 22 \\
\hline $\mathrm{Si}$ & 5.781 & 5.750 & 7.127 \\
\hline $\mathrm{Al}$ & 2.219 & 2.250 & 0.873 \\
\hline $\mathrm{Al}$ & 0.093 & 0.130 & 0.147 \\
\hline $\mathrm{Ti}$ & - & - & 0.002 \\
\hline $\mathrm{Fe}^{*}$ & 0.006 & 0.005 & 1.198 \\
\hline $\mathrm{Mg}$ & - & - & 4.824 \\
\hline $\mathrm{Mn}$ & - & - & 0.004 \\
\hline $\mathrm{Ca}$ & 0.028 & 0.043 & 0.146 \\
\hline $\mathrm{Na}$ & 0.982 & 0.841 & 0.008 \\
\hline $\mathrm{K}$ & 0.891 & 0.921 & 0.071 \\
\hline
\end{tabular}

$334-22-2,52-55 \mathrm{~cm}$ and from 0.16 to $0.19 \mathrm{wt} \%$ in $334-$ $27-1,38-50 \mathrm{~cm}$.

Plagioclase is rare within the peridotites and where present is highly altered. Plagioclase analyses from Sample $334-22-2,52-55 \mathrm{~cm}$ range from 99 to 88 mole \% An with an average value of 95 . Plagioclase compositions range from 87 to 92 mole \% An in olivine gabbros (334-24-3, 55-58 cm and 334-27-1, 38-50 cm) and from 78 to 87 mole \% An in olivine-free gabbro (334-21-1, 36$47 \mathrm{~cm}$ ). In general, the plagioclase crystals have broad

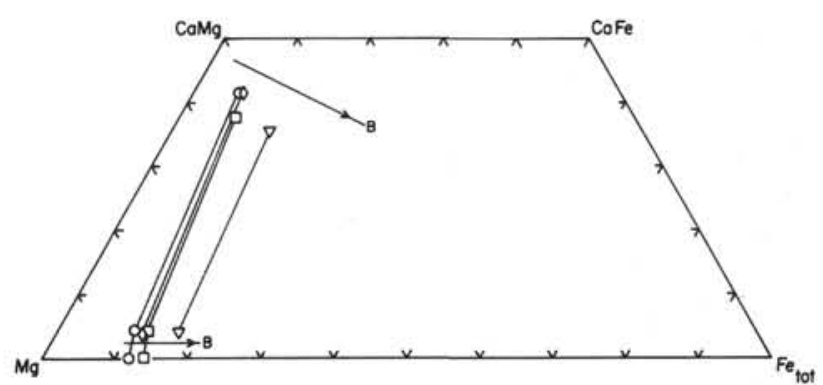

Figure 9. Average broad-beam analysis of Site 334 pyroxene plotted on pyroxene quadrilateral. Lines marked $B$ are Bushveld pyroxene trends. Points along $\mathrm{Mg}$ $\mathrm{Fe}_{\text {tot }}$ join represent olivine compositions. 21-1, 36$47 \mathrm{~cm} ; 22-2,52-55 \mathrm{~cm} ; 24-3,55-58 \mathrm{~cm} ; 27-1$, $38-50 \mathrm{~cm}$.

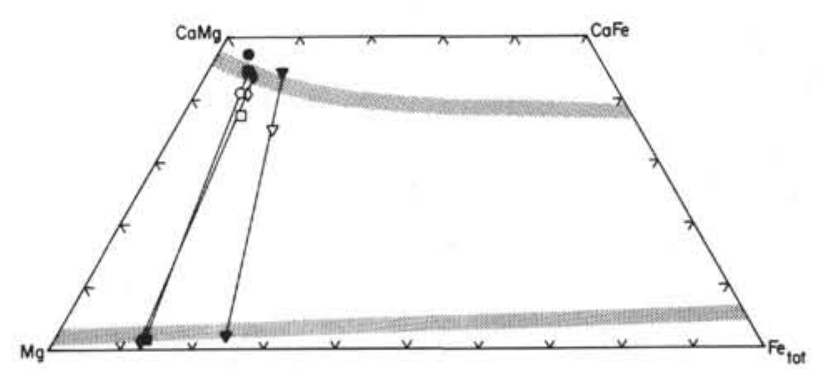

Figure 10. Average microprobe analyses of exsolution lamellae and host (closed symbols), for Site 334 pyroxenes plotted on pyroxene quadrilateral. Symbols as in Figure 9. Bands represent approximate $810^{\circ} \mathrm{C} \mathrm{sol}$ vus (Lindsley et al., 1974).

cores with compositions near the anorthite-rich end of the range, most compositional variation taking place within relatively narrow rims. The $\mathrm{FeO}^{*}$ contents range from $0.20 \mathrm{wt} \%$ in olivine gabbro $(334-27-1,38-50 \mathrm{~cm})$ to $0.58 \mathrm{wt} \%$ in olivine-free gabbro (334-21-1, 36-47 $\mathrm{cm}$ ); however, $\mathrm{MgO}$ is below the microprobe detectability limit for all analyzed plagioclases, in strong contrast to plagioclase from deep-sea volcanic rocks (Bryan, 1974).

Chrome-rich spinels in the peridotites and gabbros show little compositional variation (Figure 3 ), although there is a slight tendency for lower $\mathrm{Mg} / \mathrm{Mg}+\mathrm{Fe}^{2+}$ in the olivine gabbros. The analyses plot within the compositional fields of both alpine peridotites and large stratiform intrusions (Irvine, 1967). The Site 334 spinels are comparable in chromium content to spinels reported from deep-sea basalts (Frey et al., 1974; Ridley et al., 1974; Mazzullo et al., 1976); however, they are more iron-rich than spinels of comparable chromium content. The differences in $\mathrm{Mg} / \mathrm{Mg}+\mathrm{Fe}^{2+}$ may be significant, but are more likely a reflection of the paucity of mineralogical data from deep-sea basalts.

Amphiboles within the coarse-grained rocks occur as anhedral, ragged grains of pargasite within the peridotite and as euhedral to subhedral overgrowths of tremolite on clinopyroxenes in altered areas within olivine gabbros. The compositions of both quadrilateral and other components (Papike et al., 1974) 
within the two amphiboles are remarkably similar, probably reflecting the chemical similarity of the materials from which the two amphiboles formed. However, the tremolites contain less than $20 \%$ "other" components, being principally quadrilateral, while the pargasites contain only $20 \%$ quadrilateral components. The strong difference in the amount of "other" components in the two amphiboles almost surely reflects strong differences in the conditions of formation.

The petrology and mineral chemistry of the Leg 37 peridotites and gabbros indicate that they are the crystallization products of low-alkali olivine tholeiite magma. The preponderance of clinopyroxene over orthopyroxene in these rocks indicates a basic dissimilarity between these rocks and those commonly found in ophiolite suites along continental margins (Moores and MacGregor, 1972). The well-developed exsolution textures and extreme degree of equilibration within the pyroxenes indicates long and slow cooling and annealing at relatively high temperatures, probably deep within layer 3 of the oceanic crust, with latestage tectonic emplacement to their present high crustal level. The presence of pargasitic amphibole within the peridotites, very different in composition from amphiboles forming under the present low-temperature regime, indicates that amphibole-bearing peridotite may be an important constituent of layer 3 , and that it could be important in the production of calcalkaline andesites from subducted plates (Kushiro, 1974).

\section{ACKNOWLEDGMENTS}

The authors are indebted to W. Holzwarth for assistance with the electron microprobe and to $\mathrm{K}$. Baldwin for assistance with the sorting and plotting routines applied to the microprobe data. This work was supported by NSF Grant DES74-22511.

\section{REFERENCES}

Bryan, W.B., 1974. Fe-Mg relationships in sector-zoned submarine basalt plagioclase: Earth Planet. Sci. Lett., v. 24, p. $157-165$.
Frey, F.A., Bryan, W.B., and Thompson, G., 1974. Atlantic Ocean floor: Geochemistry and petrology of basalts from Legs 2 and 3 of the Deep-Sea Drilling Project: J. Geophys. Res., v. 79, p. 5507-5527.

Hess, H.H., 1941. Pyroxenes of common mafic magmas: Am. Mineral., v. 26 , p. 515-535, 573-594. 1960. Stillwater igneous complex: Geol. Soc. Am., Mem. 80 , p. 1-230.

Irvine, T.N., 1967. Chromian spinel as a petrogenetic indicator, Part 2. Petrologic applications: J. Earth Sci., v. 4, p. 71-103.

Kushiro, I., 1974. Melting of hydrous upper mantle and possible generation of andesitic magma: An approach from synthetic systems: Earth Planet. Sci. Lett., v. 22, p. 294-299.

Lindsley, D.H., King, H.E., Jr., and Turnock, A.C., 1974. Compositions of synthetic augite and hypersthene coexisting at $810^{\circ} \mathrm{C}$ : Applications to pyroxenes from lunar highlands rocks: Geophys. Res. Lett., v. 1, p. 134-136.

Mazzullo, L.J., Bence, A.E., and Papike, J.J., 1976. Petrography and phase chemistry of basalts from DSDP Leg 34. In Hart, S.R., Yeats, R.S., et al., Initial Reports of the Deep Sea Drilling Project, Volume 34: Washington (U.S. Government Printing Office), p. 245-262.

Moores, E.M. and MacGregor, I., 1972. Types of alpine ultramafic rocks and their implication for fossil plate interactions: Geol. Soc. Am. Mem., v. 132, p. 209-223.

Mottl, M.J., Corr, R.F., and Holland, H.D., 1974. Chemical exchange between sea water and mid-ocean ridge basalt during hydrothermal alteration: An experimental study (abstract): Geol. Soc. Am. Abstract with Programs, v. 7, p. $879-880$.

Papike, J.J., Cameron, K.L., and Baldwin, K., 1974. Amphiboles and pyroxenes: Characterization of other than quadrilateral components and estimates of ferric iron from microprobe data (abstract): Geol. Soc. Am. Abstract with Programs, v. 7, p. 1053.

Ridley, W.I., Rhodes, J.M., Reid, A.M., Jakes, P., Shih, C., and Bass, M.N., 1974. Basalts from Leg 6 of the Deep-Sea Drilling Project: J. Petrol., v. 15, p. 140-159.

Skinner, B.J. and Peck, D.L., 1969. An immiscible sulfide melt from Hawaii: Econ. Geol. Monogr., No. 4, p. 310322.

Wager, L.R., Brown, G.M., and Wadsworth, W.J., 1960. Types of igneous cumulates: J. Petrol., v. 1, p. 73-85. 
PLATE 1

Figure 1 Sample 332B-2-5, 109-111 cm under crossed nicols. Long dimension of photomicrograph approximately $3 \mathrm{~mm}$.

Figure 2 Sample 332B-71-1, 27-30 cm under crossed nicols. Composite olivine grain with $120^{\circ}$ grain intersection. Long dimension is approximately $3 \mathrm{~mm}$.

Figure 3 Sample 332B-21-1, 27-30 cm under plane light. Skeletal quench olivine and plagioclase. Long dimension of photomicrograph approximately 0.5 $\mathrm{mm}$.

Figure 4 Sample 332B-19-1, 107-110 cm under crossed nicols. Skeletal quench clinopyroxene. Long dimension of photomicrograph approximately 0.5 $\mathrm{mm}$. 


\section{PLATE 1}
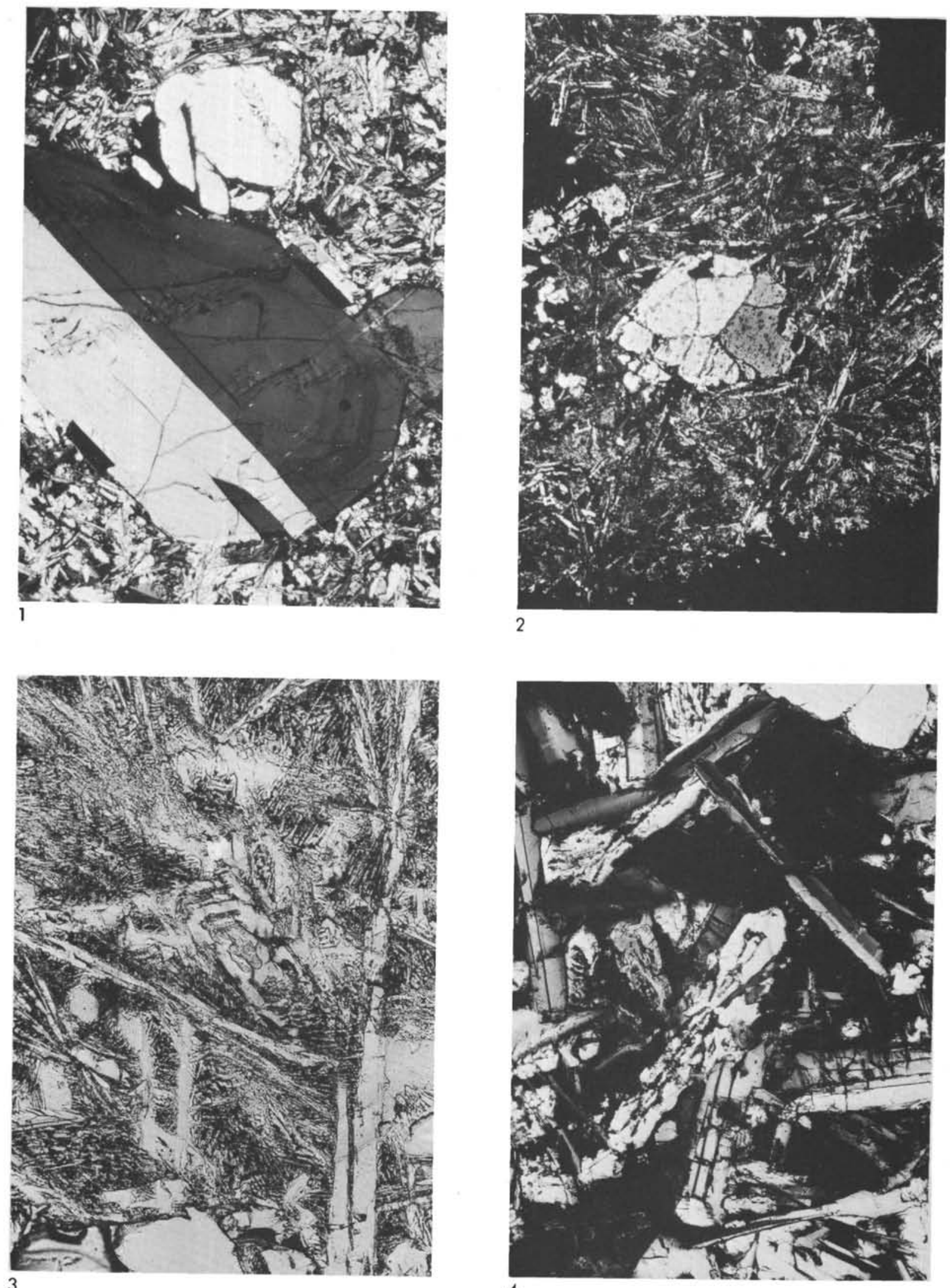


\section{PLATE 2}

Figure 1 Sample 332B-22-4, 18-20 cm under plane light showing intergrowth of olivine and plagioclase. Long dimension of photomicrograph approximately $3 \mathrm{~mm}$.

Figure 2 Sample 332B-19-1, 107-110 cm under plane light. Euhedral zeolite crystals projecting into calcite. Long dimension of photomicrograph approximately $0.5 \mathrm{~mm}$.

Figure 3 Sample 334-27-1, 38-50 cm under crossed nicols. Exsolved augite in olivine gabbro with fringe of tremolite adjacent to olivine grain. Long dimension is approximately $3 \mathrm{~mm}$.

Figure 4 Sample 334-21-1, 36-47 cm under crossed nicols. Twinned augite with (001) and (100) exsolution. Long dimension of photomicrograph approximately $3 \mathrm{~mm}$. 
PLATE 2

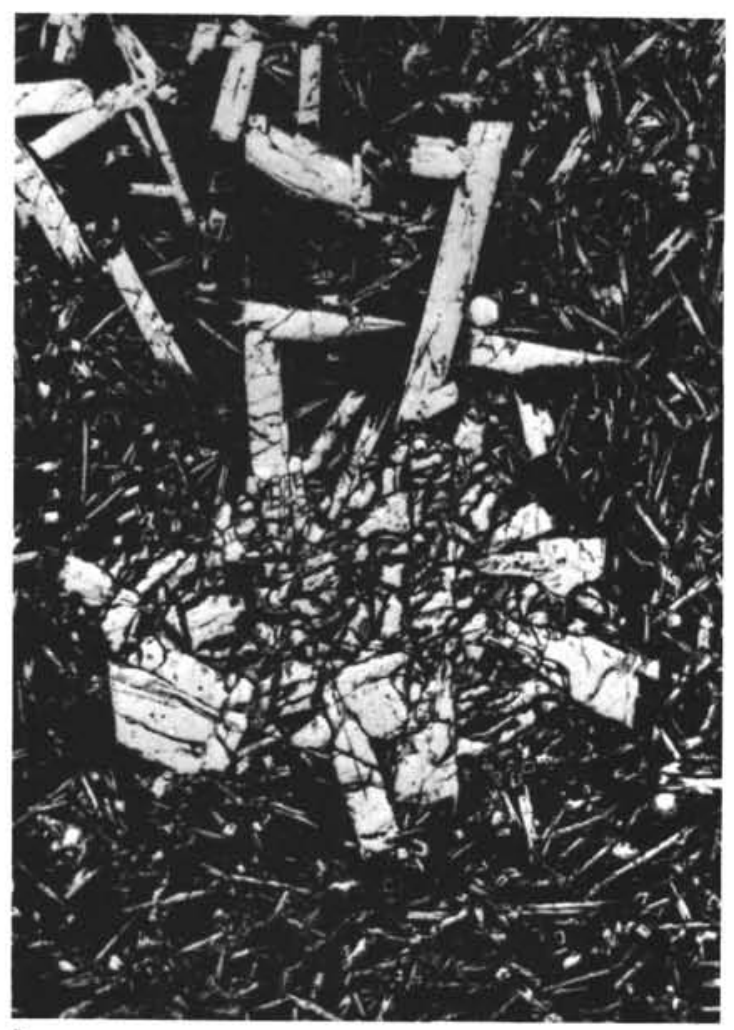

1

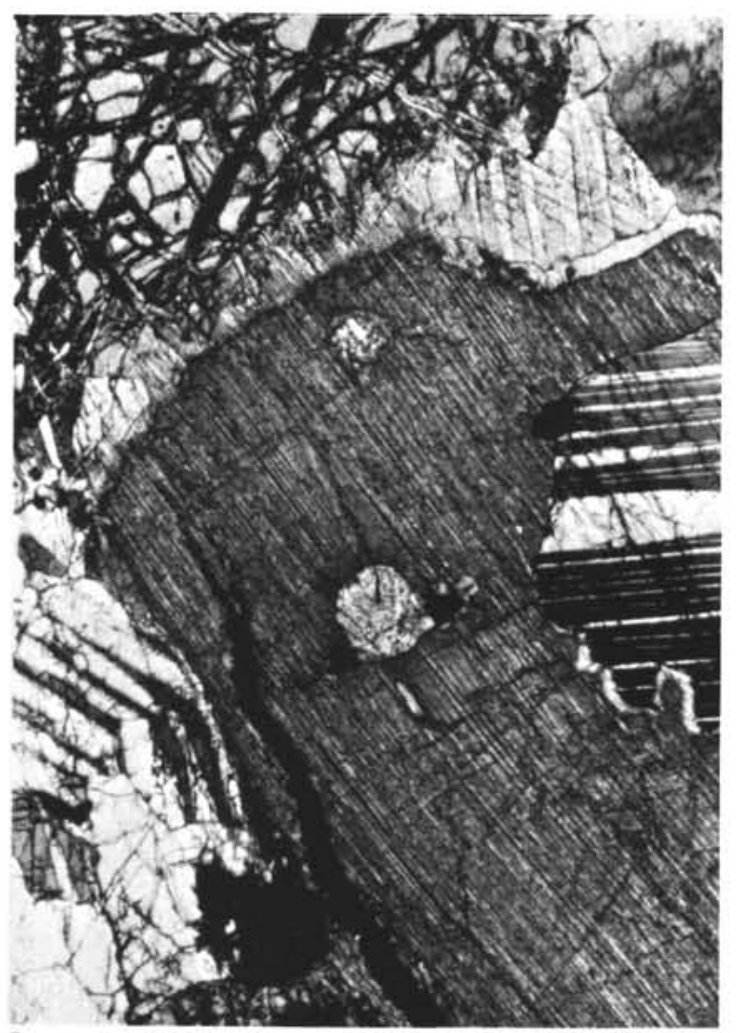

3
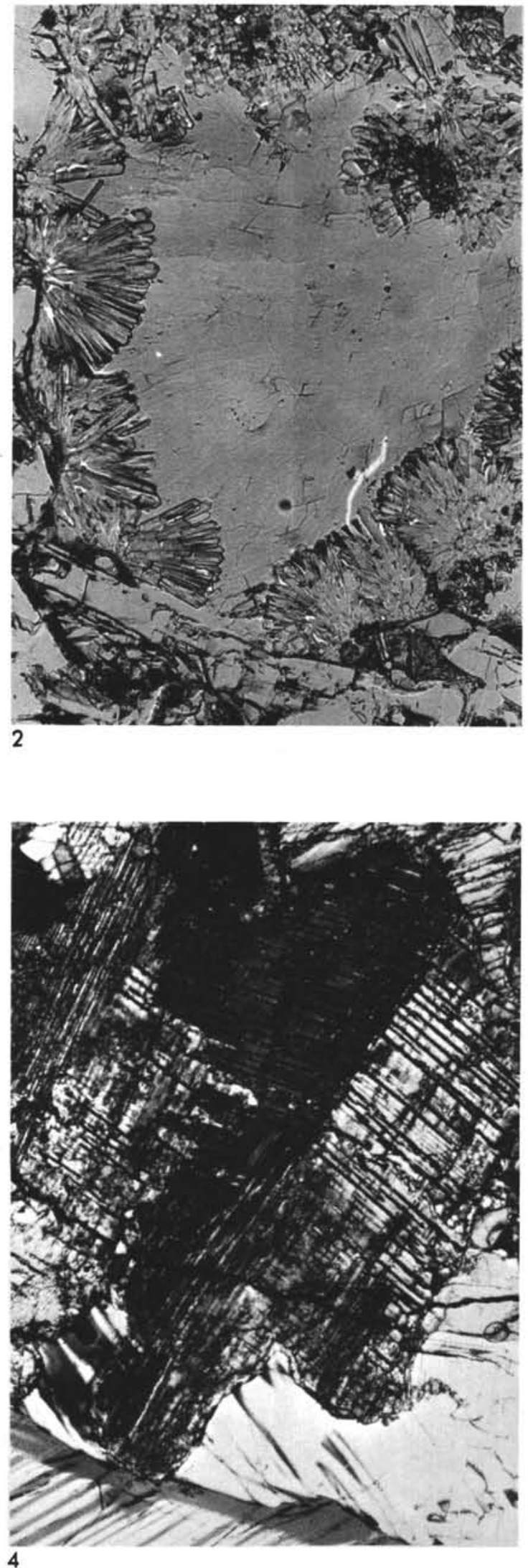